\title{
Introduction and Molecular Characterization of Tomato yellow leaf curl virus in Okinawa, Japan
}

\author{
Shigenori UEDA ${ }^{1 *}$, Masatoshi ONUKI ${ }^{1}$, Keisuke KIJIMA ${ }^{2}$, \\ Kazuyasu FUTAGAMI ${ }^{2}$, Kinue KINJO ${ }^{2}$, Yuko MURAYAMA ${ }^{3}$, \\ Masahiro TANIGUCHI ${ }^{2}$ and Shinji KAWANO ${ }^{3}$ \\ ${ }^{1}$ National Agricultural Research Center for Kyushu Okinawa Region, National Agriculture and Food \\ Research Organization (Koshi, Kumamoto 861-1192, Japan) \\ ${ }^{2}$ Okinawa Prefectural Plant Protection Center (Naha, Okinawa 902-0072, Japan) \\ ${ }^{3}$ Okinawa Prefectural Agricultural Research Center (Itoman, Okinawa 901-0336, Japan)
}

\begin{abstract}
Tomato yellow leaf curl disease (TYLCD) caused by Tomato yellow leaf curl virus (TYLCV) has been identified in Okinawa Prefecture, a subtropical region in Japan, for the first time in 2007. Infected tomato plants were collected from Tomigusuku City, Uruma City, Yomitan-son, and Nakijin-son on the main island of Okinawa. The complete nucleotide (nt) sequence of the TYLCV-Israel[Japan:Tomigusuku:2007] (TYLCV-IL[JR:Tom:07]) isolate obtained from Tomigusuku was determined. The sequence comparison with four representative TYLCV isolates in Japan showed that TYLCV-IL[JR:Tom:07] was most closely related to TYLCV-Israel[Japan:Tosa:2005] (TYLCV-IL[JR:Tos:05]), a member of the Israel strain of TYLCV (TYLCV-IL). The phylogenetic relationship analyses were performed based on determined partial nucleotide sequences of approximately 1,400 nt of 14 other isolates collected from 7 distinct locations. All the Okinawa isolates were separated into the cluster including TYLCVIL[JR:Tos:05] and at least 2 distinct isolates of the TYLCV-IL were introduced onto the main island of Okinawa. These results indicated that the introduction of TYLCV into Okinawa might have been caused by domestic transportation of infected plants.
\end{abstract}

Discipline: Plant disease

Additional key word: Tomato yellow leaf curl disease

\section{Introduction}

Tomato yellow leaf curl disease (TYLCD) caused by Tomato yellow leaf curl virus (TYLCV; genus Begomovirus, family Geminiviridae) is one of the most devastating viral diseases affecting tomato plants worldwide ${ }^{12,13,16,17}$. Infected tomato plants possess leaves exhibiting chlorotic and curled-up margins; the plants are stunted and the flowers abscised. TYLCV possesses a monopartite singlestranded DNA (ssDNA) genomic component (DNA-A) encapsidated in geminate particles, and it is transmitted by the whitefly, Bemisia tabaci (Genn.). TYLCV was first identified in Israel ${ }^{3,4}$, and the two viral genomic DNA populations represented a mixture of two TYLCV strains (TYLCV-Israel (TYLCV-IL) and TYLCV-Mild (TYLCVMld)) differing in symptom severity ${ }^{1}$ TYLCV has been classified under several viral species ${ }^{5,13,19}$. The TYLCV complex consisting of TYLCVs and distinct geminivirus species belonging to the genus Begomovirus, has been associated with TYLCD ${ }^{13}$. Recent geminivirus taxonomic and nomenclatural updates are published by the ICTV Geminiviridae study group ${ }^{6}$. Fauquet et al. ${ }^{6}$ proposed the species TYLCV consists of five strains; TYLCV-IL, TYLCV-Mld, TYLCV-Iran, TYLCV-Gezira, and TYLCV-Oman.

In Japan, the first evidence of TYLCD caused by TYLCV was recorded in 1996 in Shizuoka and Aichi Prefectures in Tokai district, central Japan, and in Nagasaki Prefecture in Kyushu district, located in southwest Japan'. To date, TYLCV has spread across 32 prefectures and has caused significant agricultural damage concerning the production of tomato fruits and Eustoma grandiflorum flowers in Japan.

Analyses of the complete nucleotide (nt) sequences of these isolates demonstrated that the isolates obtained from

*Corresponding author: e-mail sued@affrc.go.jp

Received 31 October 2007; accepted 25 June 2008. 
Tokai district belonged to the TYLCV-Mld strain, while an isolate obtained from Kyushu district was identified as the TYLCV-IL strain ${ }^{9,14,21}$. Furthermore, the TYLCVIsrael[Japan:Tosa:2005] (TYLCV-IL[JR:Tos:05]) was identified in Kochi Prefecture in Shikoku district. TYLCV-IL[JR:Tos:05] possessed a unique molecular genetic structure and was supposed to be a distinct invasive isolate $^{22}$.

Okinawa is the southernmost prefecture of Japan, and the only prefecture that is located in a truly subtropical region. In this study, we report for the first time an outbreak of TYLCD in Okinawa Prefecture in 2007. The first detection of TYLCV was in Tomigusuku City. Since then, TYLCV has been identified in many locations, and has caused substantial yield losses to tomato fruit production on the main island of Okinawa. In order to obtain knowledge of the TYLCV invasion and to facilitate TYLCV diagnosis and management, we performed the nucleotide sequence and molecular phylogenetic relationship analyses of isolates collected from distinct locations. We also discussed efficient TYLCV management strategies that could be developed under the subtropical conditions in Okinawa.

\section{Materials and methods}

\section{Viral origin and maintenance of isolates}

Naturally infected tomato plants exhibiting typical symptoms of the yellow leaf curl disease were collected at Zayasu, Tomigusuku City, in January 2007 and at Zayasu and Noha, Tomigusuku City; Gushikawa, Uruma City; Kina, Yomitan-son; and Nakaoshi, Nakijin-son, Okinawa Prefecture, in March 2007 (Table 1, Fig. 1). The viral isolate obtained from Zayasu in January was maintained by graft inoculation onto Solanum lycopersicum cv. Hausumomotaro (tomato). The inoculated plants were grown in an insect-proof greenhouse at a constant temperature of $26^{\circ} \mathrm{C}$ with a day length of $16 \mathrm{~h}$.

\section{DNA-A nucleotide sequence analyses}

Total DNA was extracted from young leaves of the plants by the alkaline-lysis preparation method followed

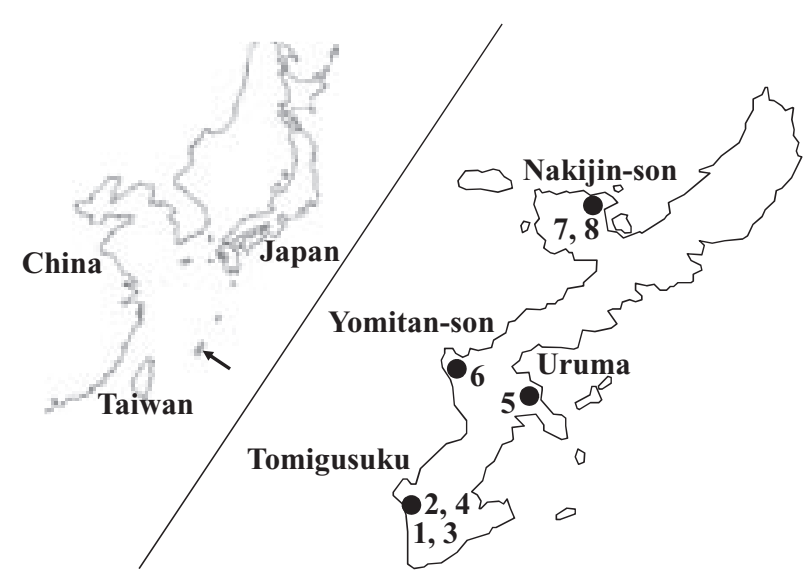

Fig. 1. Geographic map showing the locations of the sampling sites for Tomato yellow leaf curl virus (TYLCV)-infected tomato plants in Okinawa

The arrow indicates the location of the main island of Okinawa. The code numbers are listed in Table 1.

Table 1. Origins of viral samples used in this study

\begin{tabular}{|c|c|c|c|c|}
\hline Code & Geographic origin & Collected date & Infected host plant & Isolate name \\
\hline 1 & $\begin{array}{l}\text { Tomigusuku } \\
\text { (Zayasu) }\end{array}$ & January $11 / 2007$ & Solanum lycopersicum & Japan:Tomigusuku:2007 \\
\hline 2 & $\begin{array}{l}\text { Tomigusuku } \\
\text { (Zayasu) }\end{array}$ & March 5 / 2007 & Solanum lycopersicum & $\begin{array}{l}\text { TomigusukuZ2-1 } \\
\text { TomigusukuZ2-2 }\end{array}$ \\
\hline 3 & $\begin{array}{l}\text { Tomigusuku } \\
\text { (Noha) }\end{array}$ & March 5 / 2007 & Solanum lycopersicum & $\begin{array}{l}\text { TomigusukuN3-1 } \\
\text { TomigusukuN3-2 }\end{array}$ \\
\hline 4 & $\begin{array}{l}\text { Tomigusuku } \\
\text { (Noha) }\end{array}$ & March 5 / 2007 & Solanum lycopersicum & $\begin{array}{l}\text { TomigusukuN4-1 } \\
\text { TomigusukuN4-2 }\end{array}$ \\
\hline 5 & $\begin{array}{l}\text { Uruma } \\
\text { (Gushikawa) }\end{array}$ & March 6 / 2007 & Solanum lycopersicum & $\begin{array}{l}\text { Uruma5-1 } \\
\text { Uruma5-2 }\end{array}$ \\
\hline 6 & $\begin{array}{l}\text { Yomitan-son } \\
\text { (Kina) }\end{array}$ & March 6 / 2007 & Solanum lycopersicum & $\begin{array}{l}\text { Yomitan6-1 } \\
\text { Yomitan6-2 }\end{array}$ \\
\hline 7 & $\begin{array}{l}\text { Nakijin-son } \\
\text { (Nakaoshi) }\end{array}$ & March 5 / 2007 & Solanum lycopersicum & $\begin{array}{l}\text { Nakijin7-1 } \\
\text { Nakijin7-2 }\end{array}$ \\
\hline 8 & $\begin{array}{l}\text { Nakijin-son } \\
\text { (Nakaoshi) }\end{array}$ & March 5 / 2007 & $\begin{array}{l}\text { Solanum lycopersicum } \\
\text { (weedy cherry tomato) }\end{array}$ & $\begin{array}{l}\text { Nakijin8-1 } \\
\text { Nakijin8-2 }\end{array}$ \\
\hline
\end{tabular}


by precipitation with 2-propanol ${ }^{15}$. PCR was carried out using Ex Taq polymerase (Takara Co. Ltd., Shiga, Japan) according to the manufacturer's instructions. To amplify the cDNA of the entire viral genomic DNA for sequencing, Polymerase Chain Reaction (PCR) was performed with a method using 2 sets of primers that has been described previously ${ }^{21}$. In order to determine the complete genomic sequence of the isolate obtained from Zayasu in January, the PCR-amplified fragments were cloned into the pGEM-T EASY vector (Promega, Wisconsin, USA) and used for sequencing. In order to analyze the molecular genetic structure and grouping of the TYLCV isolates, the amplified PCR products of 14 isolates (from 7 different locations), were used for direct sequence determination. The partial nt sequences (PNSs, approximately 1,400 nt in length) including the entire nt sequences of the intergenic region (IR), V2 and C4, and parts of the nt sequences of $\mathrm{V} 2$ and $\mathrm{C} 1$ regions, were analyzed by using the following primers: TYNT7 5'-TTCCTCATCACTTGAAACCT-3' and TYNT9 5'-TGTATTGGGCTCGTAAGTTT-3'. The nt sequences were determined by using the BigDye terminator cycle sequencing kit v3.1 (Applied Biosystems, California, USA) and were resolved by using the ABI PRISM 3100-Avant Genetic Analyzer (Applied Biosystems). The sequence data were assembled and analyzed by using the GENETYX software (GENETYX Co. Ltd., Tokyo, Japan) and the BLAST program (http://www.ncbi. nlm.nih.gov/BLAST/).

\section{Phylogenetic relationship analyses}

The entire sequences of DNA-A genome of the following selected TYLCV-IL and TYLCV-Mld isolates were used for analyses as detailed in Table 2. Their sequences included previously reported representative isolates of Japan, and recently deposited sister isolates of TYLCVIL[JR:Tos:05] from foreign countries. Descriptions of viral isolates follow those contained in the publication by Fauquet et al. ${ }^{6}$. Sequence alignments were generated by using the CLUSTAL $\mathrm{W}^{20}$ or $\mathrm{X}$ programs ${ }^{8}$. We used the phylogenetic relationships based on PNSs of 15 TYLCV isolates collected in Okinawa, together with those of 9 TYLCV isolates based on PNSs, instead of the DNA-A complete nt sequences. The phylogenetic relationships of TYLCV isolates were determined by methods using the neighbor-joining (NJ), the minimum-evolution (ME) and the maximum-parsimony (MP) algorithms, running on the MEGA2.1 software (http://www.megasoftware.net/).

\section{Results and discussion}

In order to determine the complete nt sequences of TYLCV isolated from the site of the first TYLCV outbreak in Tomigusuku City in Okinawa Prefecture, we collected infected tomato plants in January 2007. This isolate (TYLCV-Israel[Japan:Tomigusuku:2007] (TYLCV-IL[JR: Tom:07])) was determined to be 2,780 nt in length, and the nt sequences were deposited into the DDBJ/EMBL/ Genbank database (accession number AB363566). The DNA-A nt sequences of TYLCV-IL[JR:Tom:07] were closely related to those of TYLCV-IL[JR:Tos:05] (98\%) and TYLCV-IL[JR:Omu:Ng] (97\%) (Table 3). This result clearly showed that TYLCV-IL[JR:Tom:07] was a member of the strain TYLCV-IL. The nt sequences of the intergenic region (IR) of TYLCV-IL[JR:Tom:07] were most closely related to those of TYLCV-IL[JR:Tos:05] (97\%). However, the amino acid sequences of the V2 and C3 regions of TYLCV-IL[JR:Tom:07] were more closely related to those of TYLCV-IL[JR:Tos:05] (V2, 98\%; C3, 98\%), TYLCV-Mld[JR:Shz] (V2, 98\%; C3, 97\%) and TYLCV-Mld[JR:Aic] (V2, 98\%; C3, 96\%), than to those of TYLCV-IL[JR:Omu:Ng] (V2, 97\%; C3, 95\%) (Table $3)$. This chimeric molecular genetic characterization of TYLCV-IL[JR:Tom:07] was coincident with that of TYLCV-IL[JR:Tos:05] between the strains of TYLCV-IL and TYLCV-Mld ${ }^{22}$.

In order to analyze the phylogenetic relationships

Table 2. Reference TYLCV sequences and their DDBJ/EMBL/GenBank accession numbers

\begin{tabular}{lll}
\hline \hline Isolate name & Abbreviation & Accession no \\
\hline Tomato yellow leaf curl virus-Israel[Israel:Rehovot:1986] & TYLCV-IL[IL:Reo:86] & X15656 \\
Tomato yellow leaf curl virus-Israel[Mexico:Culiacan:2005] & TYLCV-IL[MX:Cul:05] & DQ631892 \\
Tomato yellow leaf curl virus-Israel[China:Shangai 2:2005] & TYLCV-IL[CN:SH2:05] & AM282874 \\
Tomato yellow leaf curl virus-Israel[United States:California:2007] & TYLCV-IL[US:Cal:07] & EF539831 \\
Tomato yellow leaf curl virus-Israel[Turkey:Mersin:2005] & TYLCV-IL[TR:Mer:05] & AJ812277 \\
Tomato yellow leaf curl virus-Israel[Japan:Tosa:2005] & TYLCV-IL[JR:Tos:05] & AB192965 \\
Tomato yellow leaf curl virus-Israel[Japan:Omura:Ng] & TYLCV-IL[JR:Omu:Ng] & AB110217 \\
Tomato yellow leaf curl virus-Mild[Japan:Shizuoka] & TYLCV-Mld[JR:Shz] & AB014346 \\
Tomato yellow leaf curl virus-Mild[Japan:Aichi] & TYLCV-Mld[JR:Aic] & AB014347 \\
\hline
\end{tabular}


Table 3. Percentage nucleotide and amino acid identities for TYLCV-IL[Japan:Tomigusuku:2007] with four different representative isolates collected from Japan

\begin{tabular}{|c|c|c|c|c|c|c|c|c|}
\hline & \multicolumn{2}{|c|}{ Nucleotide sequences } & \multicolumn{6}{|c|}{ Amino acid sequences } \\
\hline & DNA-A & IR & $\mathrm{V} 1(\mathrm{CP})$ & $\mathrm{V} 2$ & C1 (Rep) & $\mathrm{C} 2$ & $\mathrm{C} 3$ & $\mathrm{C} 4$ \\
\hline TYLCV-IL[JR:Tos:05] & 98 & 97 & 99 & 98 & 98 & 97 & 98 & 96 \\
\hline TYLCV-IL[JR:Omu:Ng] & 97 & 93 & 99 & 97 & 98 & 96 & 95 & 96 \\
\hline TYLCV-Mld[JR:Shz] & 91 & 79 & 99 & 98 & 89 & 97 & 97 & 47 \\
\hline TYLCV-Mld[JR:Aic] & 91 & 75 & 99 & 98 & 89 & 96 & 96 & 47 \\
\hline
\end{tabular}

among TYLCV isolates, we preliminarily compared the relationships based on those between PNSs and the complete nt sequences among 9 TYLCV isolates. All the results calculated by using three distinct methods were well correlated with the phylogenetic relationships between those based on PNSs and the complete nt sequences of their TYLCV isolates (data not shown). The phylogenetic tree based on PNSs constructed by using the NJ method is shown in Fig. 2. These grouping were also consistent with that obtained by using the ME and MP methods (data not shown). Based on the phylogenetic relationship analyses, the PNSs of all isolates obtained in Okinawa were separated into the cluster of the strain TYLCV-IL. Furthermore, these Okinawa isolates fell into a subcluster that included TYLCV-IL[JR:Tos:05] having a high bootstrap value distinct from the cluster that included TYLCV-IL[JR: Omu:Ng]. Of the isolates collected from Zayasu Tomigusuku City, in January (TYLCV-IL[JR:Tom:07]) and March 2007 (TomigusukuZ2-1 and Z2-2), 3 were identical, and exhibited a single branch. This result indicated that these 3 isolates collected from Zayasu, Tomigusuku City, differed distinctly from the other Okinawa isolates. Based on 12 PNSs of isolates obtained from 6 locations in Okinawa, these isolates belonged to a different subcluster that included TYLCV-IL[JR:Tos:05] and TYLCV-IL[CN: $\mathrm{SH} 2: 05]$ (from China) with a high bootstrap value.

Our results indicated that the molecular characterizations of all the isolates collected from Okinawa were similar to those of TYLCV-IL[JR:Tos:05]. The nt sequence and phylogenetic relationship analyses of the virus indicated that at least 2 distinct isolates of the TYLCV-IL were introduced into and dispersed on the main island of Okinawa. Sister isolates of TYLCV-IL[JR:Tos:05] and TYLCV-IL[JR:Tom:07] have been dominantly identified in the $\mathrm{Kanto}^{23}$ and Kansai districts (unpublished data) in Japan. In fact, we noticed that some Okinawa farmers had commonly ordered tomato seedlings from other districts in Japan. Therefore, TYLCV isolates identified in Okinawa were supposed to be introduced on viral reservoir seedlings onto the main island of Okinawa by domestic transportations. Once the introduction of TYLCV has occurred, the

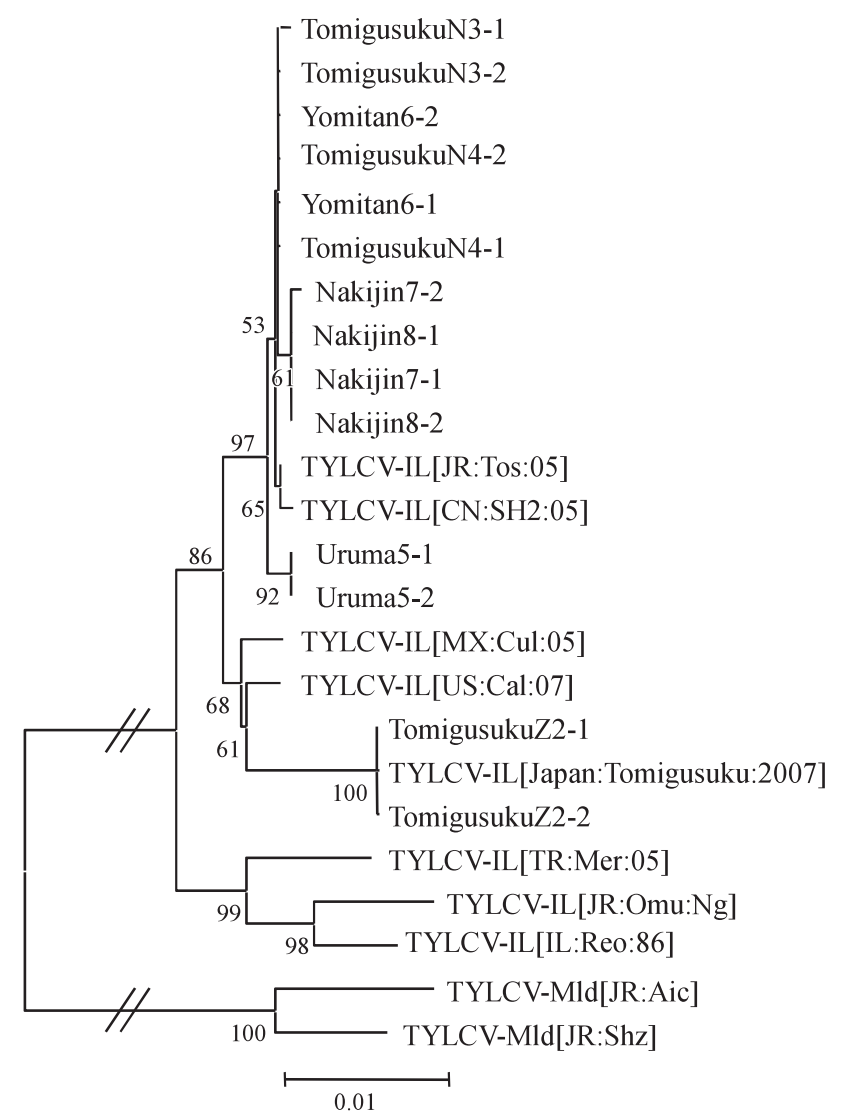

Fig. 2. Phylogenetic relationship analysis by the neighborjoining (NJ) method

Phylogenetic tree calculated by the NJ method based on 1,400 nucleotide (nt) sequences of TYLCV, including the intergenic region. The numbers appearing at each node indicate the percentage of supporting bootstrap samples (only values $>50$ are shown). The designations of the isolates (genetic variants) obtained from Japan in this study are provided in Table 1.

management of TYLCD has to begin needing extra costs and it becomes very difficult to avoid yield loss.

Okinawa lies in a subtropical climate region. The duration of the egg-to-adult stage of B. tabaci on cotton was related to temperature, and the development rates were 
similar to those on other host plants ${ }^{2}$. According to the climate reports of the Japan Meteorological Agency (http:// www.data.jma.go.jp/obd/stats/data/en/normal/normal. $\mathrm{html}$ ), the monthly mean minimum temperature (19712000) of Naha City in Okinawa is above $16.6^{\circ} \mathrm{C}$. The winter climatic conditions are supposed to be mild for vector insect propagation and growth and subsequently infection of plants, including tomato, in fields. This is entirely different from conditions on other Japanese islands (Honshu, Shikoku, and Kyushu areas). Since the first outbreak in 2007, TYLCV has been spread into many locations on the main island of Okinawa and some neighboring islands. In Japan, little is known about the management of TYLCD and whitefly in subtropical regions. The approaches of an island country such as the Dominican Republic (DO) located in the Caribbean Ocean may be an informative model for Okinawa. The DO has been associated with the implementation of a mandatory 3-month whitefly host-free period in summer in order to establish TYLCV management ${ }^{18}$. In addition, a few improved early maturing hybrid varieties and TYLCV-resistant varieties were being made available with the host-free period strategy in the $\mathrm{DO}^{7}$.

Over the last 20 years, many breeding programs have been carried out developing TYLCV-resistant cultivars in the world ${ }^{10,11,16}$. Recently developed TYLCV-resistant (or tolerant) cultivars could be commercially available in Japan. As soon as possible we have to establish effective TYLCV management strategies combining physical, chemical and biological methods in Okinawa. In addition, we need to pay attention to further viral dispersion and new invasions of both reservoir host plants and viruliferous whiteflies. The experiences of Okinawa learned in terms of TYLCV management in a subtropical region should facilitate control of insect-transmitted viral diseases in other districts in Japan.

\section{Acknowledgments}

This research was supported in part by a grant from the Ministry of Agriculture, Forestry and Fisheries (MAFF) and National Agriculture and Food Research Organization (NARO) of Japan.

\section{References}

1. Antignus, Y. \& Cohen, S. (1994) Complete nucleotide sequence of an infectious clone of a mild isolate of Tomato yellow leaf curl virus (TYLCV). Phytopathology, 84, 707-712.

2. Butler, G. D. Jr., Henneberry, T. J. \& Clayton, T. E. (1983) Bemisia tabaci (Homoptera: Aleyrodidae): development, oviposition, and longevity in relation to temperature. Ann. Entomol. Soc. Am., 76, 310-313.
3. Cohen, S. \& Harpaz, I. (1964) Periodic, rather than continual acquisition of a new tomato virus by its vector, the tobacco whitefly (Bemisia tabaci (Gennadius)). Entomol. Exp. Appl., 7, 155-166.

4. Cohen, S. \& Antignus, Y. (1994) Tomato yellow leaf curl virus, a whitefly-borne geminivirus of tomatoes. In Advances in disease vector research, vol. 10, ed. Harris, K. F., Springer-Verlag, New York, 259-288.

5. Fauquet, C. M. \& Stanley, J. (2005) Revising the way we conceive and name viruses below the species level: a review of geminivirus taxonomy calls for new standardized isolate descriptors. Arch. Virol., 150, 2151-2179.

6. Fauquet, C. M. et al. (2008) Geminivirus strain demarcation and nomenclature. Arch. Virol., 153, 783-821.

7. Gilbertson, R. L. et al. (2007) Introduction of Tomato yellow leaf curl virus into the Dominican Republic: the development of a successful integrated pest management strategy. In Tomato yellow leaf curl virus disease, ed. Czosnek, H., Springer, Dordrecht, 279-303.

8. Jeanmougin, F. et al. (1998) Multiple sequence alignment with Clustal X. Trends Biochem. Sci., 23, 403-405.

9. Kato, K. et al. (1998) The first occurrence of Tomato yellow leaf curl virus in tomato (Lycopersicon esculentum Mill.) in Japan. Ann. Phytopath. Soc. Jpn., 64, 552-559.

10. Lapidot, M. et al. (2001) Effect of host plant resistance to Tomato yellow leaf curl virus (TYLCV) on virus acquisition and transmission by its whitefly vector. Phytopathology, 91, 1209-1213.

11. Lapidot, M. (2007) Screening for TYLCV-resistance plants using whitefly-mediated inoculation. In Tomato yellow leaf curl virus disease, ed. Czosnek, H., Springer, Dordrecht, 329-342.

12. Mansoor, S. et al. (2003) Geminivirus disease complexes: an emerging threat. Trends Plant Sci., 8, 128-134.

13. Moriones, E. \& Navas-Castillo, J. (2000) Tomato yellow leaf curl virus, an emerging virus complex causing epidemics worldwide. Virus Res., 71, 123-134.

14. Onuki, M. et al. (2004) Molecular characterization and strain-specific detection of the Tomato yellow leaf curl virus occurring in Kyushu, Japan. Bull. Natl. Agric. Res. Center Kyushu Okinawa Reg., 44, 55-77 [In Japanese with English summary].

15. Palmer, K. E., Schnippenkoetter, W. H. \& Rybicki, E. P. (1998) Geminivirus isolation and DNA extraction. In Plant virology protocols, eds. Foster, G. D. \& Taylor, S. C., Humana Press Inc., Totowa, NJ, USA, 41-52.

16. Pico, B., Diez, M. J. \& Nuez, F. (1996) Viral diseases causing the greatest economic losses to the tomato crop. II. The Tomato yellow leaf curl virus: a review. Sci. Hortic., 67, 151-196.

17. Polston, J. E. \& Anderson, P. K. (1997) The emergence of whitefly-transmitted geminiviruses in tomato in the western hemisphere. Plant Dis., 81, 1358-1369.

18. Salati, R. et al. (2002) Tomato yellow leaf curl virus in the Dominican Republic: characterization of an infectious clone, virus monitoring in whiteflies, and identification of reservoir hosts. Phytopathology, 92, 487-496.

19. Stanley, J. et al. (2005) Geminiviridae. In Virus taxonomy, 8th Report of the ICTV, ed. Fauquet, C. M., Elsevier/Academic Press, London, 301-326.

20. Thompson, J. D., Higgins, D. G. \& Gibson, T. J. (1994) 
CLUSTAL W: Improving the sensitivity of progressive multiple sequence alignment through sequence weighting, positions-specific gap penalties and weight matrix choice. Nucleic Acids Res., 22, 4673-4680.

21. Ueda, S. et al. (2004) Three distinct groups of isolates of Tomato yellow leaf curl virus in Japan and construction of infectious clone. J. Gen. Plant Pathol., 70, 232-238.
22. Ueda, S. et al. (2005) Evidence of a new Tomato yellow leaf curl virus in Japan and its detection using PCR. J. Gen. Plant Pathol., 71, 319-325.

23. Ueno, T. et al. (2007) Phylogenetic analysis of Tomato yellow leaf curl virus collected from various localities in Kanto area. Nihon Shokubutsu Byourigakukaihou (Jpn. J. Phytopathol.), 73, 221 [In Japanese]. 